\begin{tabular}{c} 
International Journal of Engineering \& Technology, 7 (4) (2018) 2149-2152 \\
International Journal of Engineering \& Technology \\
SPC \\
Website: $\begin{array}{c}\text { ww. sciencepubco.com/index.php/IJET } \\
\text { doi: } 10.14419 / \text { ijet.v7it.12918 } \\
\text { Research paper }\end{array}$ \\
\hline
\end{tabular}

\title{
Assessing the future prospects of solar energy conversion technologies in electronic applications
}

\author{
Dr. Maha Abdul ameer Kadhim ${ }^{1}$ \\ ${ }^{1}$ Middle Technical University (MTU) Technical Instructors Training Institute, assistant professor. Baghdad, Iraq \\ *Corresponding author E-mail: Mahakahdum@gmail.com
}

\begin{abstract}
Solar energy has become one of the most important sources of renewable energy. This is evident in the fact that many organizations and individuals have resorted to renewable energy, without fear of depletion, without fear of the monthly costs of using fuel-based electricity. The study examined the mechanism of using solar energy and the mechanism of solar cells in converting sunlight into electricity in general, and thus allocating research in solar energy conversion technologies to electrical energy, and some systems of assessing of these technologies, in order to know the future status of the technology of converting solar energy, as well as to know the costs that these technologies must reach in order to be a candidate for bulk power.
\end{abstract}

Keywords: Solar; Renewable; Energy; Chemical Energy; Light.

\section{Introduction}

Energy is Vitality is characterized as the capacity to play out an action. There are numerous sorts of vitality, the most vital of which are warm, light, stable, mechanical vitality created by hardware, concoction vitality produced by synthetic responses, and hydroelectric vitality, motor, outspread, dynamic, and atomic. Energy can be converted from one type to another, such as converting chemical energy into photovoltaic energy, and electric to kinetic [1].

The amount of energy in the world is always constant, it can neither be created nor destroyed; rather, it can only be transformed from one type to another. Classification of energy and its sources is based on the possibility of renewing and maintaining that energy. This classification includes depleted energy, which includes coal, petroleum, and natural gas. It is called the depleted because it cannot be manufactured again, or compensated again in a short time. The classification also includes renewable, clean or alternative energy, which includes hydroelectric energy, wind energy, solar energy, biomass energy, seawater energy (Tides) and underground geothermal energy [2].

By focusing on solar energy in this research, solar radiation has the greatest flow of energy entering the earth ecosystem. 100,000TW of solar energy is hitting the earth after absorption and reflection; so, it has a huge effect when converting it into electrical and thermal energy, through photovoltaic transformation and warm change of sun based vitality. Photovoltaic change alludes to the transformation of sun oriented or optical radiation specifically into electrical vitality by photovoltaic cells. Some photovoltaic transformation materials are called semi-conductors, for example, Celsius, Germanium, and so on [3].

A few physicists found this marvel in the late 1800s; they found that light could discharge electrons from a few metals, and they realized that blue light had a more noteworthy capacity than yellow light to discharge electrons [4].

Many models of solar cells have been manufactured for producing electricity. It does not consume fuel nor pollute the atmosphere, in addition to its long life, and little requirement of maintenance. So, it can be installed on the roofs of buildings to benefit from the production of electricity, usually estimated efficiency of about $20 \%$, the rest can be used to provide heat for warming, and to heat water. Solar cells are also used to operate the various communications system, in lighting roads and buildings, in pumping water and others [5].

The interest in the conversion of solar energy developed until the early fifties, when the development of high-strength segments of silicon was placed in certain forms and dimensions, and able to convert sunlight into electricity, but the cost was very high. It was the first use of solar panels manufactured from Silicon in telecommunications in remote areas. And then, solar energy was used to supply satellites with electric power, where the sun is bright for (24) hours a day and is still used to this day [6].

This study aims to assess the future prospects of Solar Energy Conversion Technologies in electronic applications; it also aims to search the current techniques used in converting solar energy into electrical energy and implementing it in electronic applications.

\section{Research objectives}

The fundamental point of this investigation is to :

Evaluate the future prospects of Solar Energy Conversion Technologies in electronic applications Sub-points are:

1) Review the current technologies of energy conversion in electronic applications.

2) Review different models for assessing the PV technologies.

3) Accelerate the commercialization of energy technologies.

\section{Research problem}

Albeit sun based vitality has accepted a critical place in sustainable power source options, its utilization is related with the nearness of daylight all through its utilization. In this way, there is a marvelous 
necessity for the progression of intensity and warm change of sun based essentialness, despite the change of advancements to store the imperativeness to misuse in the midst of the season of vanishing sun situated radiation [7]. There are a few strategies for putting away sunlight based vitality, including warm, mechanical, synthetic and attractive stockpiling. Sun based capacity look into is a standout amongst the most critical regions of improvement in sun powered applications and its spread over a wide range. Albeit sunlight based vitality is accessible, it isn't reasonable and isn't free in the sense. Its genuine cost spoke to in the gear used to change over sunlight based vitality from electromagnetic vitality to electrical or warm vitality, notwithstanding capacity if vital [8].

One of the main reasons for the serious consideration of the exploitation of clean and sustainable energy, such as solar energy, is the depletion of conventional energy sources, like coal, oil and gas, which is expected by 2030 , the risks resulting from the exploitation of nuclear energy, in addition to the increasing rise in pollution rates due to greenhouse gas emissions from the world's permissible limits, and its relation to climate changes caused by global warming. The main reasons for these dangers are the use of traditional energy sources such as oil and gas [9], which contribute about $26 \%$ in emissions as shown in figure (1).

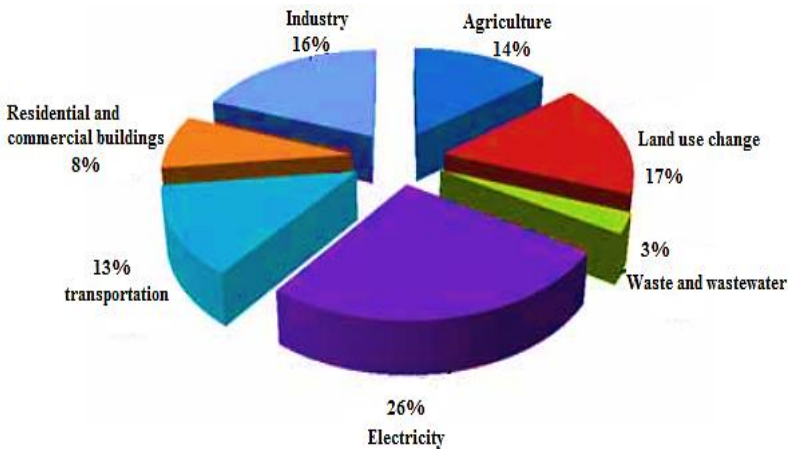

Fig. 1: Relative Equivalent Distribution of Carbon Dioxide Emissions Sources Globally [10].

\section{Research significance}

Since the Industrial Revolution, the interest in vitality has expanded colossally, and petroleum products have turned into the principal decision as appeared in figure (2). Nonetheless, the mischief caused by this fuel and its non-lastingness prompted the thought of different wellsprings of vitality. Sun-powered vitality was the first of these sources.

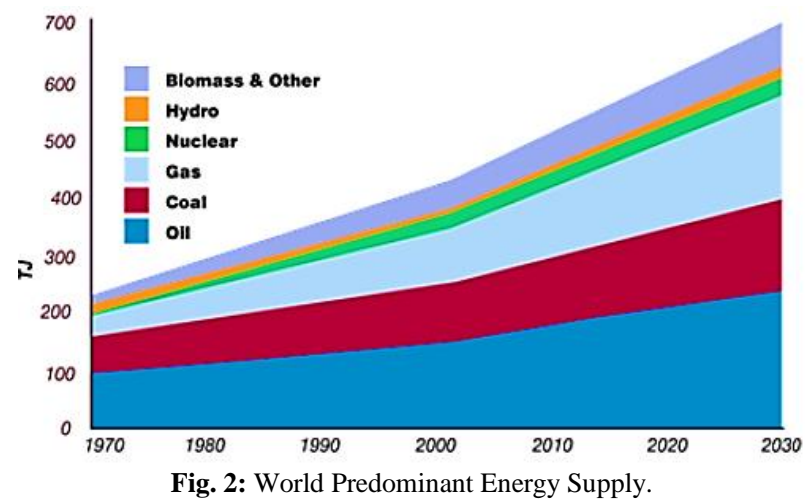

The issue of the use of new and renewable energy, especially Concentration Solar Power (CSP), has emerged on the global arena as one of the strategic options for meeting future local and global energy needs.

It is clear that there is a strong relationship between the success of development and the availability of energy. This added a very important dimension, which is reflected in the depletion of traditional sources of energy over the next 30 years, in addition to the continuous rise in global pollution rates, especially for large urban centers as the most energy-intensive [11].

\section{Renewable energy}

Sustainable power source mirrors the vitality got from inexhaustible common assets, which can't be finished. Economic vitality and its sources vary from non-renewable energy sources, similar to oil, coal, and flammable gas, or atomic fuel utilized as a part of atomic reactors.

The most significant feature of renewable energy is the zero emissions of $\mathrm{CO} 2$ or harmful gases, in addition to its importance as a solution of the increased warming problem, unlike fossil fuels or harmful atomic residue from nuclear reactors. Renewable energy is produced, from water as in figure (3), from wind as in figure (4)or from sun, and energy can be produced, from the movement of waves and tides, as in figure (5), or from the heat of the earth as in figure (6) [12].

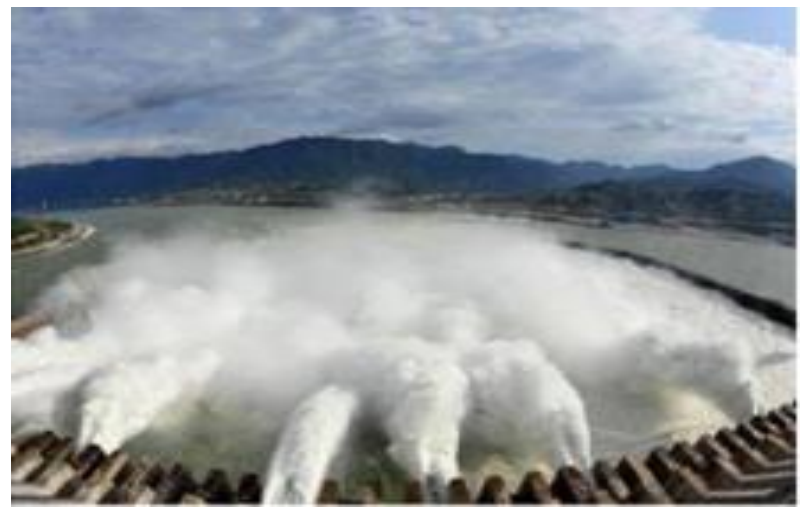

Fig. 3: Hydropower behind Dams [2]

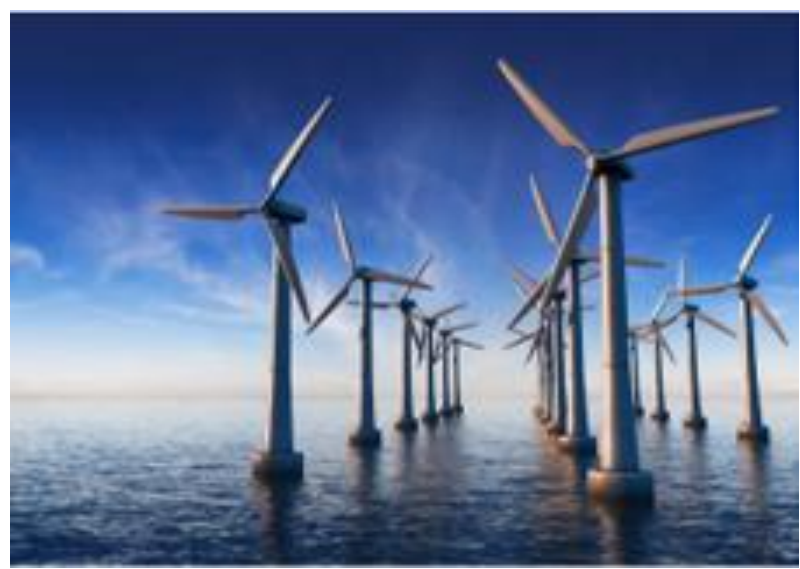

Fig. 4: Wind Turbines [1]

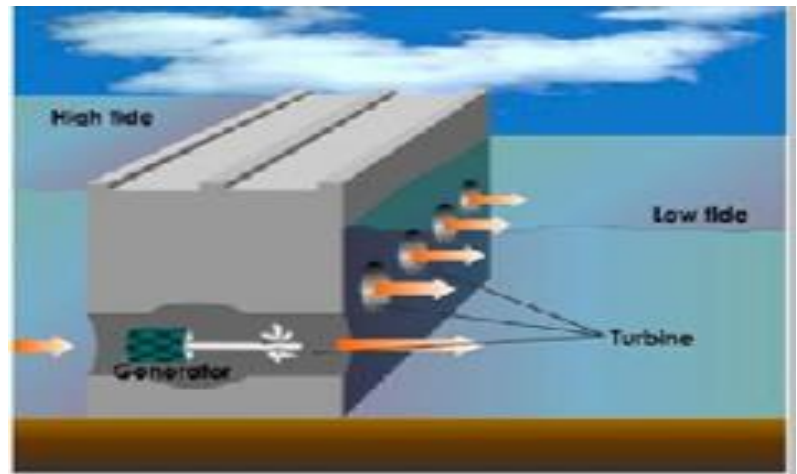

Fig. 5: Tidal Power Station. 


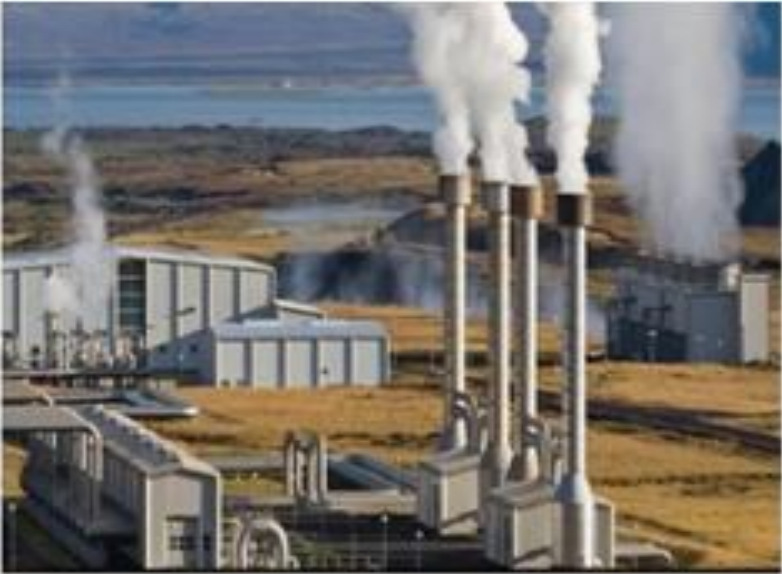

Fig. 6: Electric Power from the Core of the Earth.

what's more, sun powered controlled advances are broadly utilized as a part of created and some creating nations; be that as it may, the methods for delivering power utilizing inexhaustible wellsprings of vitality have turned out to be typical as of late .

Numerous nations have wanted to expand their extent of sustainable power source generation to cover their vitality needs by $20 \%$ of their utilization by 2020. At the Kyoto Conference in Japan, most heads of state agreed to decrease carbon dioxide age in coming quite a while to dodge the noteworthy perils of natural change caused by tainting. Petroleum product exhaustion, and in addition the social and political dangers of non-renewable energy sources and atomic vitality [13].

\section{Solar cells}

Solar cell systems convert solar energy directly into electrical energy. They are also considered to be the best applications of renewable energy for lighting and water pumping in remote areas with small streams and scattered homes away from the electrical grids. These systems have limited operation and maintenance costs compared to the default life span to 20-23 years.

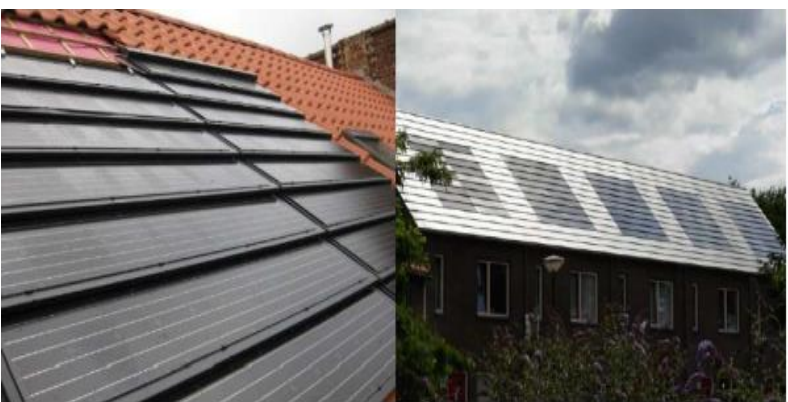

Fig. 7: Solar Cells on Houses' Roofs [14]

Solar cell systems consist of a silicon layer that has some impurities to give it some electrical properties. The upper layer corresponding to the sun is added to the phosphorus component, to give it the property of pumping the kernels when the particles hit it, this layer is called $\mathrm{n}$. While the element of boron is added to the lower layer and gives it the property of absorption of the kernels, this layer is called P (Kibert, 2016).

When the solar beam is hit by the upper layer, the kernels give energy based on the intensity of the solar radiation. When an electrical conductor exists between the two layers, the kernels move from the upper layer to the lower layer. Solar cells are an important source for providing spacecraft and satellites with the necessary electrical energy. Figure (8) is show an example of solar cells [15]

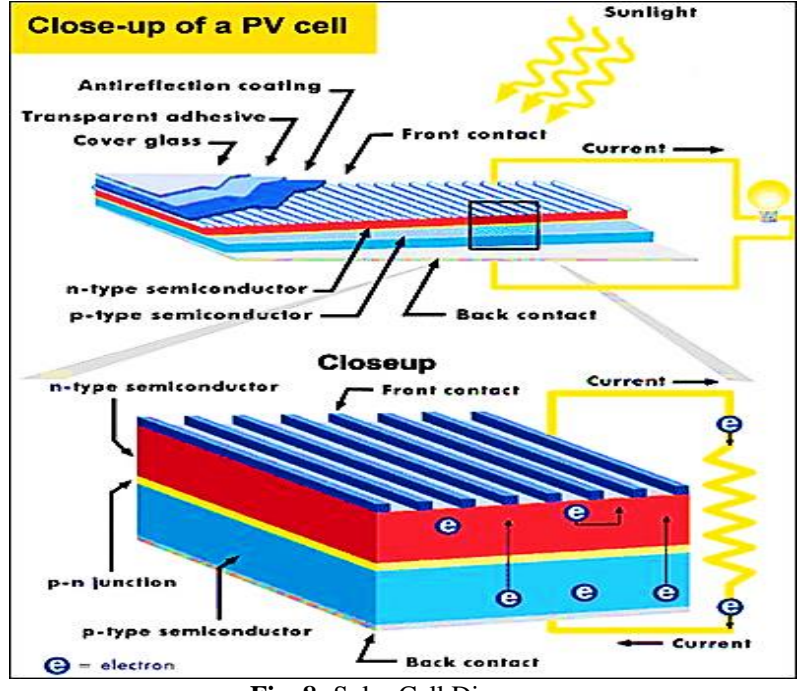

Fig. 8: Solar Cell Diagram.

The solar cells convert solar energy directly into electricity and are characterized by the production of electricity without causing pollution of the environment, and the default life of up to 30 years. The high cost of production is the main obstacle to its use [16].

\section{Photon-to-electric energy conversion tech- nology}

In Photon-to-Electric Energy Conversion Technology, the prompt power generation from light absorption is permitted by the gadgets of Photovoltaic. The energy of absorbing photons in the photovoltaic system by semiconductors is equal to or greater than its bandgap. In this system, the parity band electron is boosted to the band of conduction at a time of photon absorption, and it has the freely moving capability out of the bulk of the semiconductor, in order to be held for current generation.

In the devices of photovoltaic that made of mineral semiconductors the splitting process of charge is done by the built-in electric field at the p-n junction. But, organic photovoltaic have different operation, as the molecular orbitals is used for determining the electronic and optical features of the materials of organic semiconductor. While the features of molecule, and its band-gap, are specified by the Lowest Unoccupied Molecular Orbital (LUMO) and Highest Occupied Molecular Orbital (HOMO), as in figure (9). Exciton formation is produced due to assimilation of light in small molecules or in conjugated polymers [17].
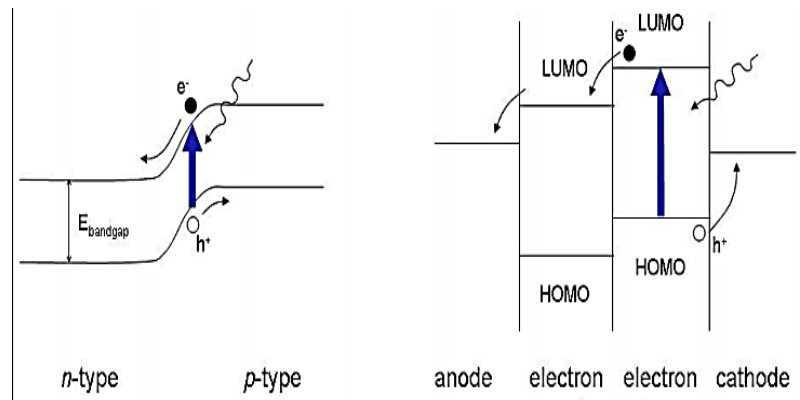

acceptor donor
ig. 9: P-N Junction Scheme (Left), Structural Organic Bilayer (Right)

In Organic Bilayer systems, the determination of the efficiency is depending on the excitons' requirement for attaining the interface of donor-acceptor, as the transferring of charges are done before recombination happens, and the transportation of charges to the electrodes are done subsequently, before back transferring of electrons from acceptor's LUMO to the donor's HOMO [18]. 


\section{Investigation of existing work on solar pho- tovoltaic technologies and deployment}

Azzopardi et al. (2009) (23) studied different photovoltaic systems that are commercially available, sustainability assessment and Life Cycle Analysis (LCA) are reviewed in this study, notwithstanding the correlation between new half and half quantum dab (QD)-based sun based modules and business PV. In 2008 a review was done on 26 business advances of PV as appeared in table (1)

Table 1: PV Technologies [19]

\begin{tabular}{|c|c|c|c|}
\hline major category & subeategory & major cateegory & subeategory \\
\hline 1. crystalline-Si & $\begin{array}{l}\text { 1a. c-Si } \\
\text { 1b. mc-Si, wafer-based } \\
\text { 1c. mc-Si, ribbon or sheet } \\
\text { 1d. mc-Si, novel }\end{array}$ & 4. excitonic & $\begin{array}{l}\text { 4a. organic, small molecule } \\
\text { 4b. organic, polymer } \\
\text { 4c. dye-sensitized TíO } \\
\text { 4d. hybrid organic/inorganic }\end{array}$ \\
\hline 2. thin-film & 2a. a-Silmultijunction a-Si & 5 novel hich-efficiency & $\begin{array}{l}\text { 4e. quantum dot composite } \\
\text { 5a. hot carprier }\end{array}$ \\
\hline & $\begin{array}{l}\text { 2c. CdTe } \\
\text { 2d. ClS and related alloys } \\
\text { 2e. polycrystalline multijunction } \\
\text { 2f. novel materials }\end{array}$ & & $\begin{array}{l}\text { 5b. multiple electron-hole pair } \\
\text { 5c. multiband } \\
\text { 5d. frequency up/down conversion } \\
\text { 5e. plasmonics }\end{array}$ \\
\hline 3. concentrator & $\begin{array}{l}\text { 3a. c-Si, up to } 100 x \\
\text { 3b. c-Si, } 100-1000 x \\
\text { 3c. III-V multijunction, up to } 100 x \\
\text { 3d. III-V multifiunction, 100-1000x } \\
\text { 3e. novel }\end{array}$ & & 5f. thermophotovoltaics \\
\hline
\end{tabular}

It demonstrated that normal PV cost is required to be $\$ 1.20 / \mathrm{Wp}$ (Peak Watts) by 2030; notwithstanding its need to be at $\$ 0.30 / \mathrm{Wp}$ to be a possibility for mass power. Also, it found that researches and development of PV must be continued by governments to reduce the cost and uncertainty; in addition to that, governments must be aware of huge deployment subsidies.

Study of Sheikh (2013) used the hierarchical decision modeling and expert judgment quantification, to find that $\mathrm{C}$-Si technology had the highest ranked technology; a-Si technology is the second one. OPV had the minimum ranked technology, and it recommended to allow OPV to gain the highest rated technology were supported as operationalization case study.

Power matrix has a noteworthy part in PV advances, so writing audit of grid-connected frameworks of PV will be led. Four parameters of execution were expressed by Marion et al. (2005) in the National Renewable Energy Laboratory (NREL) for frameworks of grid-connected PV, which are the final yield of PV system, rating of PVA, performance ratio, and reference yield. It found that shown that grid valence (the solar energy cost in order to have a high competitive ratio with traditional electricity) is $\$ 2 / \mathrm{Wp}$ for installed PV. PV technologies and applications are spreading and deploying in a fast manner. Despite the descending in incentives of European government by 2011, the development is predicted to keep going in the worldwide driven by strategies of deployment.

Study conducted by Bowden, Honsberg \& Schroder (2010) emphasized that the production of PV is essential, as unlimited sunshine is used by PV for producing electricity. But, presently PV's support of the total electricity supply is small. For raising PV's contribution, the rate development must protect of over $40 \%$ with volume preparations of 4 extent orders. Moore's Law can help in demonstrating if PV can achieve the required rates of development comparable incorporated circuits (ICs) (Nelson, 2010).DeGroat, Morabito, Peterson \& Smestad (2009) proposed an approach of systems analysis for the adoption of solar energy, it helped the diversity of public and decision makers. It found that there are three significant sides of the deployment case of solar acceleration; the rate development must protect of over $40 \%$ with volume preparations of 4 extent orders Moore's Law can help in demonstrating if PV can achieve the required rates of development comparable incorporated circuits (ICs) (Nelson, 2010)

\section{Conclusion}

Photovoltaic (PV) has a high importance in energy generation process, because of its modularity and simplicity. So, there is a huge necessity to increase the efficiency of energy conversion depending on different researches and developments; in addition to the importance of decreasing the price by depending on deployment incentives.

There are different technologies of PV, such as c-Si, a-Si, mc-Si; OPV. Assessing processes and models of these photovoltaic technologies from different views, like the view of national policy, electric utility, photovoltaic manufacturers, etc. have the ability in providing guidance on the development fields of a chosen technology.

\section{References}

[1] World Bank (2010). Development Report and Climate Change, Al Ahram Center for Publishing, Translation and Distribution.

[2] Schulze, T. F., \& Schmidt, T. W. (2015). Photochemical upconversion: present status and prospects for its application to solar energy conversion. Energy \& Environmental Science, 8(1), 103-125. https://doi.org/10.1039/C4EE02481H

[3] Butler, K. T., Frost, J. M., \& Walsh, A. (2015). Ferroelectric materials for solar energy conversion: photoferroics revisited. Energy \& Environmental Science, 8(3), 838-848. https://doi.org/10.1039/C4EE03523B.

[4] Zhang, J. (2015). Assessment of Renewable Energy Potentials Based on GIS and RS: A Case Study in China (Doctoral dissertation, Universitätsbibliothek Dortmund).

[5] Andersen, J. (2015). Modelling and Optimisation of Renewable Energy Systems, master thesis, Aarhus University, Denmark.

[6] Dusmanescu, D., Andrei, J., \& Subic, J. (2014). Scenario for implementation of renewable energy sources in Romania. Procedia Economics and Finance, 8, 300-305. https://doi.org/10.1016/S22125671(14)00094-X

[7] Torzillo, G., \& Seibert, M. (Eds.). (2018). Microalgal Hydrogen Production: Achievements and Perspectives (Vol. 16). Royal Society of Chemistry.

[8] Al-Khateeb, M. (2015). The Role of Photovoltaics in Energy Conservation and Architectural Form of Gaza Strip Residential Buildings, Master thesis, The Islamic University of Gaza, Palestine.

[9] WASET (2018). CREST 2018: 20th International Conference on Renewable Energy Sources and Technology. Retrieve from: https://waset.org/conference/2018/04/kyoto/ICREST

[10] Kibert, C. J. (2016). Sustainable construction: green building design and delivery. John Wiley \& Sons.

[11] Reddy, T. A., Kreider, J. F., Curtiss, P. S., \& Rabl, A. (2016). Heating and Cooling of Buildings: Principles and Practice of Energy Efficient Design. CRC Press. https://doi.org/10.1201/9781315374567.

[12] Grant, K. (2013). How do solar photovoltaic (PV) actually work? Retrieve from: http://www.solarbarbados.com/2013/12/07/solarphotovoltaics-pv-actually-work/

[13] Bujac, F. (2014). Evaluating the potential of renewable energy sources in Romania, Master Thesis, and Aalborg University.

[14] Bosshard, P., Hermann, W., Hung, E., Hunt, R., \& Simon, A. J. (2016). An assessment of solar energy conversion technologies and research opportunities. GCEP Energy Assessment Analysis, 45.

[15] Curtright, A. E., Morgan, M. G., \& Keith, D. W. (2008). Expert assessments of future photovoltaic technologies.

[16] Marion, B., Adelstein, J., Boyle, K., Hayden, H., Hammond, B., Fletcher, T., \& Rich, G. (2005, January). Performance parameters for grid-connected PV systems. In Photovoltaic Specialists Conference, 2005. Conference Record of the Thirty-first IEEE (pp. 1601-1606). IEEE.

[17] Yang, C. J. (2012). Reconsidering solar grid parity. Energy policy, 38(7), 3270-3273. https://doi.org/10.1016/j.enpol.2010.03.013.

[18] Bowden, S., Honsberg C. \& Schroder D. (2014). Moore's Law of Photovoltaics, Future Photovoltaics.

[19] Nelson B. (2014). Gauges Can Take PV to Its Gold Medal Game, Future Photovoltaics. 